\title{
AFRO-COMMUNITARIANISM AND THE QUESTION OF INDIVIDUAL FREEDOM
}

\author{
Jonathan O. Chimakonam \\ Philosophy Department \\ University of Pretoria \\ South Africa \\ Chukwuemeka I. Awugosi \\ Philosophy Department \\ University of Calabar \\ Nigeria
}

\begin{abstract}
In this essay, we explore the possibility and the extent of individual freedom within the Afro-communitarian set up. We contend that every community is made up of individuals whose association constitutes the community and as such, that the idea of individual freedom is not only possible but could be necessary. Granted that the idea of communitarianism presupposes the domination of communal values over individual endowments, we contend, nonetheless that when the idea of primordiality of private liberty is taken into account, individual freedom could be defended. We engage extant literature in Afro-communitarianism to make a strong case using Michael Eze's 'realist perspectivism' as a veritable index that defines the relationship between the individual and the community as contemporaneous which balances private liberty with public authority. Thus, we claim that since the freedom of the individual to function is necessary for the community to function, individual freedom is defensible insofar as it does not conflict with public authority.
\end{abstract}

\section{N T R O D U C T I O N}

Is the functioning of the individual dependent on its freedom or is it simply determined by community that subsumes her? To answer this question, we must first determine the location of freedom. Is freedom not located in agency? That is, is freedom not a property of a moral subject? If we agree that it is, then we must determine whether 
the abstract notion of the community qualifies as a moral agent. As an abstract notion cannot qualify as a subjective entity that can stand on its own without the individuals that make it up, we must deny the community moral agency, at least, the type awarded to individuals who possess the capacity for freewill and choice. Since the individual possesses this capacity and the community does not, we can then resolve that the functioning of the individual is a product of its freedom.

It is then this freedom that activates the natural desire and yearning in humans to be free from restrictions and regulations, especially the ones that hamper their full functioning as moral subjects. It is sometimes said that the individual does not exist in isolation, not because it cannot but because, for it to function to full capacity, it needs other individuals. Community is what happens when individuals come together and draw up rules to guide their relationships. Granted that in some cases, these rules are treated as supreme and any violations are punished, they are still products of individuals exercising freewill and can be repealed through the same exercise of freewill by the affected individuals. The community is thus a collection of rules formulated and endorsed by free individuals. Without individuals there cannot be rules, and without rules to govern the relationships of free individuals, there cannot be community. Afrocommunitarianism is then the doctrine that explains how the relationships of free individuals affirm the structure of the community by the individuals' striving to approximate total observance of the rules they have enacted to govern their relationships. The so-called community values are then nothing more than the norms formulated and endorsed by the individuals themselves. This, in a way, reflects the position of social contract theories variously articulated by the likes of Hobbes, Locke and Rousseau where the formation of the community necessitated the regulation of unbridled freedoms which individuals possess.

Part of our claim in this work is that the community is not self-made, it is created by individuals. This implies at least, that the individual precedes the community ontologically and it would be anathema to claim otherwise. If individuals precede their community, then it is not, cannot and ought not be the case that communal values are prior to individual endowments. Sometimes, when we talk of communal values, we tend to over-price them and treat them as rights or properties possessed by a subjective moral agent, which is incorrect. Communal values as we observed earlier are norms formulated by individuals and the community itself is a social construct created by individuals by coming together and prescribing a set of rules to guide their relationships. By the way, an individual must first be free before they can observe rules. In other words, if the observance of communal laws bends the individual below the community, then, the individual was first free before they became unfree. The individual created the community as a freely choosing social being before the community began to re-create them as politically constrained moral subjects.

Studied closely, we can begin to observe that the community is not strictly different from the individuals because it is the individuals that make it up. This community, whatever it is and possibly can be, lacks the capacity to subordinate individual endowments unless the individuals have so freely given up such endowments for their 
collective interest. So, even though Afro-communitarianism like the unqualified version ${ }^{1}$ of communitarianism discussed in Western scholarship presupposes the priority of certain communal values over individual endowments, such has to be restricted to individual duty to the community. For example, given the option of; (1, covering one's crime which may disquiet the communal peace and social stability and (2, confessing one's crime which may restore communal peace and social stability, what should the individual do? We believe that this is where the idea of the priority of communal values comes in.

The only thing that maintains social stability in a community set up by individuals is upholding its laws. Individuals who set up a community and formulate a set of laws to govern it accept the duty to observe and keep those laws they enacted. In the two options above, 1 is duty to self, 2 is duty to community; it is clear that 2 has a stronger moral pull because under the circumstance, the priority of communal values over individual endowments is best for most individuals in the community. It may not be the best for the individual who is going to be punished; for example, a murder crime may be punished by death or life sentence, this may not benefit the offender but it will benefit most of the individuals in the community through the restoration of social stability. Thus, the essence of talk about prioritizing communal values is really not to benefit the community as opposed to the individuals but to benefit most individuals because the community is nothing but a collection of individuals. So, duty to community is actually duty to fellow individuals as a group. Talk about the community is also, actually, talk about individuals who have freewill to make choices, dignity to protect which helps them to make good choices and above all, identity which singles them out for reward or retribution accruing from their free choices.

In this work, we shall first highlight the meaning and nature of freedom. We shall also discuss the substance of Afro-communitarianism and show the extent of individual freedom in Afro-communitarianism. We shall employ Michael Eze's realist perspectivism to drive home our proposal of 'binary complementarity' as the structure of the individualcommunity relationship in order to establish and defend individual freedom within Afrocommunitarianism.

\section{THE MEANING OF FREEDOM}

Ethicists tend to place high premium on the concept of freedom whether in terms of freedom to act, will, judge or broadly, freedom to choose, if without it, they can hardly justify any moral theory. To hold a moral agent culpable or to say that they are responsible for their actions implies that one grants the agent freedom of choice. One is then a moral agent because, among other things, they are believed to have the freedom to make their choices. But exactly what freedom means in itself is hardly clear. The meaning of the term as Isaiah Berlin $(1967,3)$ will make us understand is so malleable that there is little interpretation that it seems able to resist. Some ethicists for example, the utilitarians and hedonists would conceive freedom in terms of what leads to happiness or sadness, pleasure or pain as the case may be. This may not be enough but it gives us a glimpse 
into the nature of the concept. Libertarians to be specific view freedom as a priceless entitlement and an inalienable feature of the individual even though some like John Rawls (1971, 1993), Amartya Sen $(1999,2009)$ and Martha Nussbaum $(2003,2015)$ observe a caveat, that is, they also recognize that this cannot mean that everyone should be free to do whatever they please. Indeed, not even Robert Nozick $(1974,160)$ who believes that "liberty upsets patterns" clearly subscribes to the type of liberty without the above caveat. This is because, for Nozick's minimal state to function, it is not only state power over the individual that should be limited, liberties of individuals should also be constrained otherwise, no individual will be free to enjoy their liberties without the interference of other envious individuals. So, when we talk of freedom, we may be tasked to specify our scope.

It does seem therefore that context might be useful in discussing or conceptualizing freedom. When we talk about individual freedom in Afro-communitarianism what do we really wish to communicate? One thing that comes to mind is the suggestion that an individual exists in the community as a moral subject irrespective of what the role and influence of the community is on their persons. We may therefore conceive freedom following this direction as the fundamental principle of agential action. This means that freedom which an agent possesses is that principle that pre-qualifies any action taken by that agent to be adjudged moral or immoral. If we fail then to recognize this freedom of the individual within the community, it will be futile attempting to make moral judgments on their actions.

This word 'freedom' according to Friedrich Hayek (1960), is a scenario where an individual can act out of their freewill and choice without any constraint as opposed to the scenario in which one's actions and inactions are determined by another. This conception by Hayek shows that when an individual's action is determined by the community, or when an individual is under coercion to act, such a person can be deemed unfree. What is implied here is that individuals have to be free to choose before they can be ranked as moral agents. If anything at all, including the community interests or values obstruct the freedom of the individual, then such an individual or his action whether good or bad would be absolved of any moral blame. But we know that the functioning of any community depends to a large extent on the functioning of the individuals within it as free moral agents. This gives us the first clue on the basis of which we can challenge the idea defended in literature that in Afro-communitarianism, communal values are prior to individual endowments (see Menkiti 1984 and 2004; Ikuenobe 2006).

John Hospers (1984), following Berlin's categorization discusses freedom-from as against freedom-to as a way of showing the boundaries that exist in the range of freedoms which an individual may exercise. Freedom from the will of others is about what one is allowed to do without external interference, while freedom to do what one wishes is about what one can do out of their own will. "The more one is free from restrictions, the more one is free to do things that he could not do while bound by restrictions" (Hospers $1984,1)$. If the normative conception of individual (personhood), the type promoted by the radical communitarians like Menkiti and Ikuenobe entails acting and living according to the whims of the dominant community, could it imply that the individual's freedom to 
this extent is limited or non-existent? This provides yet another clue on the basis of which we can deflate the claim of the radical communitarians that the community precedes the individual because we know this supposition to be false. How often do we see an individual or group of individuals protest against some laws in the society? They do so because, unlike other members of their community, they have found a certain norm or norms objectionable. If the community actually dominates the individual, the way the radical communitarians paint it, why would there be room for dissent? Again, we may well learn from this that the fact that individuals in a community do nothing about the community that continues to normatively determine their actions, does not mean that they are powerless. No, they are not, because they made those norms and accepted it to regulate their freedoms for mutual safety and benefit. They can still repeal the laws if proved unsatisfactory along the line. A norm proving unsatisfactory is actually curious in our context because it simply means that it has begun to rupture certain individual endowments. And this sort of rupturing, for all intents and purposes, is beyond the scope of public authority. It means community norms in this context have begun to transgress against the endowments of individuals that formulated those norms and it would be time for such norms to go. So, the individual in the community is not really powerless before the community. In fact, it is because they are comfortable with the set of norms which they freely chose for themselves, that is, because those norms promote public authority which ensures that freedom of each individual is not further contracted and prevents each individual from exercising limitless freedom. It must be borne in mind that community-making individuals accept this condition as the best possible option, the formation of the community being a necessary evil — something that is in the best interest of all. So, the seeming draconian nature of communal values might well be a ploy by the community-making individuals to let the sleeping dog lie.

From the foregoing, we promote a libertarian ethos without justifying the radicalization of liberty. Individuals in a community are free and their freedoms determine their actions with accompanying responsibility. This responsibility is maintained by the legal structures aimed at maintaining social stability and communal peace. Thus, what the individual owes the community in their relationship is duty to observe the norms or a set of laws put in place to regulate the exercise of freedoms by all individuals in the community. This is why Danny Frederick (1997), proposes three principles for limiting individual freedom or for defining the limits to liberty. These principles include, the Harm principle which says, "people should be free to do whatever they want to do, so long as they do not harm anyone else; the Cost principle which states that people should be free to do whatever they want to, so long as they do not impose costs upon anyone else and the Pareto principle, which states that people should be free to do whatever increases the utility of at least one individual without reducing the utility of another" (Frederick 1997, 1). In light of these principles, we can infer that if individuals in a community are free to choose their actions, then communal values cannot truly override individual endowments. Individual freedom must therefore be inalienable, second-guessed only when the long-term viability of that freedom is threatened.

To entrench the importance of freedom for a moral subject, Berlin (1967) proposes

Philosophia: International Journal of Philosophy

ISSN 2244-1875

Vol. 21, No. 1, January 2020 
two notions of freedom; 'negative' freedom and 'positive' freedom. According to Berlin, freedom is when one is not obstructed from attaining his goals. Fredrick (1967) further argues that the wider the areas in which one is not obstructed by another human being, the wider that individual's freedom would be. But he quickly observes a problem that has occupied some classic English political thinkers which is; that at some point, we may have to plant the beacon and say, this is the extent to which an individual's freedom could or even, should go. This is because it should not be morally approvable in a modern political system for an individual's freedom to be limitless. This would mean that each individual has license to interfere with everyone else's freedom. The rule under such circumstance would be according to Richard Epistein $(1987,4)$ "do whatever you want to do, and the only way that anybody can stop you is to do what he wants to do first." The problem that may be associated with this type of limitless freedom understandably goes beyond the horror picture of the Hobbesian state of nature; it may even present an unavoidable danger to the construct of modern state. Berlin $(1967,157)$ argues that if individual freedom were to be limitless, “...it would entail a state in which all men could boundlessly interfere with all other men; and this kind of 'natural' freedom would lead to social chaos in which men's minimum needs would not be satisfied; or else the liberties of the weak would be suppressed by the strong." Berlin then seems to suggest that to avoid this scenario and protect the construct of the modern state, legal parameters were put in place to regulate individual freedoms. Part of what this regulation entails is what Berlin discusses as the two concepts of liberty or freedom.

Philosophers like Georg Hegel, Thomas Hobbes, J. S. Mill, John Locke, Benjamin Constant, etc., have variously engaged with the question of where to draw the line between private liberty and public authority. The former represents the area in which the individual could exercise his freedom unhindered (Berlin's negative freedom) while the latter represents the area in which the state could maintain control of the exercise of individual freedoms (Berlin's positive freedom). Berlin $(1967,158)$ formulates this question as that of the "minimum area of personal freedom." What would this minimum be? Where do we draw this line? And what should serve as our guiding criteria? This is not an easy decision to make as can be seen in the past 200 years where the problem continues to defy consensus.

Truth must be told that freedom is the primordial political concept without which we cannot talk about the formation of the first human community. We can imagine that the first human community must have been formed by someone or some persons who were exercising their natural freedoms and probably contracting those of others they pulled together as its first and possibly reluctant citizens. It seems to us that the realization of individual's natural freedom by the ancients was the most important discovery of the human mind. Indeed, there may be compelling reason to think that ancient peoples who lived isolated individual lives must have been unaware of their natural freedoms. It is a fact of biology that there is a limit to what an individual can do but there is no obvious limit to what he can imagine or even desire. The easiest way to achieve beyond one's natural abilities is thus to exercise limitless freedom on other human beings. Living as isolated individuals as the early people probably did is a simple proof that they were 
unaware of their natural freedom in its unlimited state. Not until the first human discovered they had unlimited freedom did humanity begin to live. It seems difficult to convince anyone that one who does not exercise his personal freedom is actually living. Thus, the first principle of life may be stated as 'act on the awareness that you are acting freely'. If we agree that the early humans may not have been aware of their natural freedoms until at some point in human evolution, then we must realize that with the first act of suppression, intimidation, usurpation and even murder made possible by the miracle of human relationship, the human civilization was born or at least destined to be born.

So even though the idea of unlimited freedom and what people could do with it sends shockwaves everywhere nowadays, we must realize that it was what gifted us with the first human civilization and set the stage for the sophisticated civilization we have built today. The challenge is that for every Rome that was built, there were many Carthage permanently destroyed and this is disturbing for moral philosophers who are today compelled to ask more questions about wide ranging topics in justice, rights, duties, values, the extent of power and of authority and so on. All this boils down to what to us is one of the most fundamental two-headed questions in political philosophy in our age: 'how much space can we allocate to individual freedom without jeopardizing public authority and destroying our civilization; and how much space can we allocate to public authority without endangering humanity and destroying our diversity?' One way to understand the much talked about human diversity is to think of individuals, each thinking for themselves, willing, acting and judging differently. This is not only colorful, it is what has shaped our world in the form it is presently. Even though one can also retort that diversity is in some ways the source of some of the crisis that trouble our world today, it is also in many ways the source of personal freedom. Twenty-first century philosophers must therefore find an answer to this two-headed question urgently before the rising clamor for libertarian ethics pushes us to a point of no return, where we, by our own hands would destroy and undo whatever humankind has achieved in the last five millennia or so.

Freedom, the species of it which the libertarians clamor for, that is freedom from external obstruction, could be a dangerous thing when not regulated (see Chimakonam 2017). It is also dangerous because it presupposes unlimited freedom for the citizens which might run into conflict with public authority. This unregulated freedom can destroy our civilization swiftly, or at least slow it down and with time may erode it. Our hunch is that with the rise of a dangerous type of populism - anarchistic populism in Venezuela, Hong Kong, the US and France and the rise of a new brand of state autocracy - autocratic democracies in the Philippines, Turkey, Russia and China, it is not particularly clear what the next phase of human history would be like.

Thus, the two concepts of freedom are for Berlin two of the many senses of freedom. In pursuit of his objective of discussing freedom within the scope of political philosophy, he restricted himself to these two senses he describes as negative and positive freedoms. Negative freedom for him would be that area in which there is non-interference or no obstruction from anybody as the individual pursues his goals. It would be freedom from (Berlin, 1967). This is contrasted from positive freedom which is that area in which the 
AFRO-COMMUNITARIANISM AND THE QUESTION OF INDIVIDUAL FREEDOM 41

individual exercises control over their actions and it would be construed as freedom to (Berlin, 1967).

So, for Berlin, if individuals' freedom to govern themselves is upheld in order to promote the human ideal, freedom in that sense is a positive one. It provides for what individuals are free to do. It is freedom to pursue their goals insofar as it does not encroach on others' freedoms protected by public authority. But if their freedoms are such that are not obstructed or constrained, freedom in that sense would be a negative one. It is freedom from obstruction and interference and we do not know the extent the state should regulate this freedom without destroying it. So, somehow, both senses of freedoms may run into conflict. A limitless individual freedom cannot coexist with public authority; neither can an excessive or repressive public authority coexist with individual freedom. What is needed for the thriving of the society and human civilization is a balance of the two which in Afro-communitarianism is a balance of the individual endowments and community values to orchestrate a sort of binary complementarity.

The individual endowments are the target of the attacks by the radical Afrocommunitarians led by John Mbiti (1970), Ifeanyi Menkiti (1984), Polycarp Ikuenobe (2006) and others. In the literatures, Menkiti is recognized as the father of this movement. Kwame Gyekye (1992) singled his work out as the finest statement of radical communitarianism. The radical communitarians hold that the community dominates and shapes the individual. A person is only a person through the community. He is born into the community that awards him an identity and forges his personality. Outside the community, he fades away and ceases to exist. In this conception, there is little or no room for individual freedom since a person is completely determined by the community. Menkiti $(1984,171)$ puts it more sharply, “...the reality of the communal world takes precedence over the reality of individual life histories, whatever these may be. And this primacy is meant to apply not only ontologically, but also in regard to epistemic accessibility." This means that whatever the individual is, is determined by the community. Under this circumstance, there may be much ripples with regards to Berlin's negative freedom because, the community subsumes and regulates every individual's freedom even though there can be no room for an individual to interfere or obstruct another's freedom. In the Matolino's version of limited communitarianism where the claims which the community can make are limited, the space of individual autonomy can be expanded. But Berlin's talk about individual freedom as positive may have little space in Afro-communitarianism, specifically in the radical version because the community not only regulates but clearly interferes and obstructs the individual freedom. The individual has no freedom to govern themselves. The question is; what is the individual free to do or not to do in an Afro-communitarian set up? This shall be our concern in a latter section. In the next section, we shall discuss the theory of Afrocommunitarianism.

\section{THE THEORY OF AFRO-COMMUNITARIANISM}

Afro-communitarianism roughly is a socio-political and normative theory of 
personhood that also attempts to give account of the relationship between the individual and his community from an African epistemic perspective. The theory covers indices such as power, authority, rights, justice, autonomy, equality and ultimately freedom, etc. The fundamental question is, between the individual and the community, who should have the most influence in their relationship with regards to the indices listed above?

Beginning with John Mbiti who laid the first true foundation for the emergence of the field of Afro-communitarianism, it is clear that there was going to be a prolonged debate on the question above. Mbiti's $(1970,141)$ submission is encapsulated in one condensed idea, that is; "I am because we are, since we are therefore, I am." One obvious inference to be drawn from this assertion is that Mbiti perceives the relationship between the individual and his community as something that highlights the individual's dependence on his community. He gives the very first impression that the individual is subsumed by his community to the point that he may be regarded as nothing without the community. His existence depends on the community which also defines his identity such that without the community, his personality cannot be forged. This extends from the social and political down to the normative. The values that characterize the day-today social and political life of the individual are set by the community. His endowments are nothing but entitlements or gifts from the community which he stands to lose once he violates the values set by the community. It is this initial impression created by Mbiti that influenced Menkiti who went on to radicalize the doctrine of Afro-communitarianism at least, according to his nemesis Gyekye.

The community for Menkiti (1984) takes precedence over the individual and shapes and forms the individual value system through a process of incorporation and socialization. Menkiti (1984, 171-172) further stresses that "it is in rootedness in an ongoing human community that the individual comes to see himself as man, and it is by first knowing this community as a stubborn perduring fact of the psychophysical world that the individual also comes to know himself as a durable, more or less permanent, fact of this world." Menkiti claims that personhood is not something one acquires as he is born. For him, it is a stature of a sort which one can only attain when he is well along in the society. This implies that the older one gets the more of a person he is likely to become. But he warns also that personhood is something one could succeed or fail at. Ikuenobe (2006), a notable Menkitian used the characters of Obi Okonkwo and Ezeudu in Chinua Achebe's Things Fall Apart so effectively to showcase how one can fail or succeed in achieving personhood. He who leads his life in total subservience to the norms of the community is on a sure path to achieving personhood. What this means is that the pursuit of individual interests and the exercise of one's freedom might pit one against the community as is the sad story of Okonkwo who despite his gallant personal values and achievements ended his life without achieving personhood. This is why Menkiti $(1984,176)$ explains that "personhood is the sort of thing which has to be attained, and is attained in direct proportion as one participates in communal life through the discharge of the various obligations defined by one's stations." From the above, Menkiti seems to suggest that personhood is normative, a point he made more vigorously in his "On the Normative Conception of a Person," (2004). If personhood is normative 
AFRO-COMMUNITARIANISM AND THE QUESTION OF INDIVIDUAL FREEDOM 43

and the community is the giver of the norms, it then means that the individual is never truly free from the community's influences and determinations. Thus, it seems correct to conclude that Menkiti's radical Afro-communitarianism extinguishes the possibility of individual freedom and autonomy.

But Menkiti is not the only theorist in Afro-communitarianism. Although it took a while before a real challenge to his views was mounted but when it came, it completely changed the face of the discourse. Gyekye, the Ghanaian philosopher in his "Person and Community in African Thought" $(1992,104)$ took Menkiti to task. He rejected Menkiti's submission and criticized it as radical, excessive and unrestricted type of communitarianism. Gyekye (1992, 103-104) went on to assert that "Menkiti's views on the metaphysical status of the community vis-a-vis that of the person and his account of personhood in African moral, social and political philosophy are, in my opinion, overstated and not entirely correct, and require some amendments or refinements." It is his attempt to amend Menkiti's views that resulted in what he calls moderate or restricted communitarianism. Gyekye contrasts his theory with Menkiti's and claims that a fundamental mistake in Menkiti's views is his denial of individual autonomy. Gyekye (1992) explains that in the relationship between the individual and the community, a reasonable level of autonomy is required for the individual to function fully and this autonomy is natural and inalienable. He admits that in certain contexts especially those involving the common good, the community might take precedence over the individual but that this does not imply lack of autonomy to the individual or the absolute dominance of the community. It simply suggests that both complement each other showing that none ultimately takes priority over the other.

Gyekye's $(1992,113)$ defense of this ontological parity is hinged on the thinking that the individual has two components, "as a communal being and as an autonomous, self-determining, self-assertive being with a capacity for evaluation and choice." If the first component explains its duties to the community, the second guarantees its autonomy in the community. The theory of moderate communitarianism as the name goes moderates the claims of the radical communitarians by mitigating the influence of the community and elevating the importance of the individual. However, one big mistake in this theory is that at some point, Gyekye $(1992,115)$ grants that the community may take precedence over the individual on matters concerning common good and this contradicts the claim about the autonomy of the individual and the inalienability and inviolability of human rights. This makes his Afro-communitarianism inconsistent. It is on this basis that Michael Eze (2008) and Bernard Matolino (2014) rejected Gyekye's moderate communitarianism and proposed their 'realist perspectivism' and 'limited communitarianism' respectively.

For Eze, realist perspectivism is an Afro-communitarian theory that employs the principle of comtemporaneity to posit the ontological equality of the individual and the community. As Eze $(2008,386)$ puts it, "[T] he relationship between the individual and community is dialogical for the identity of the individual and the community is dependent on this constitutive formation. The individual is not prior to the community and neither is the community prior to the individual." His goal from the onset was to distance his 
theory from the dominant position in Africanist discourse which is radical communitarianism. He also sought to distance his theory from that of the moderate communitarians when he stated that "... "the politics of common good within the African value system can neither be described nor represented through consensus or unanimity but through a realist perspectivism or a worldview not held in abstraction from living traditions, cultures, and values that characterize the people(s) of sub-Saharan Africa" (Eze 2008, 386). On this score, Eze objects to Gyekye's claim that common good provides a ground for the community to lord it over the individual. Eze's thinking or suggestion is that when the relationship between the individual and the community is properly understood as something that is mutually complementary or dialogical, then, there would not be room to conceive one as being prior at some point or context. $\mathrm{He}$ (2008, $386)$ therefore, posits that " $[\mathrm{C}]$ ontemporaneity explains this dialogic relationship and to argue otherwise threatens the individual's subjectivity to a vanishing point, or simply, to deny the individual a presence." Eze's submission is that the best way to look at the relationship between the individual and the community in Afro-communitarianism is from a realist perspective because, the individual has to be autonomous to function properly in a society even though the exercise of his freedom should not be in such a way that would threaten the community. This for Eze is what is realistic.

To construct his theory of limited communitarianism, Matolino first took Gyekye to task. Matolino $(2009,169)$ rejects Gyekye's moderate communitarianism as inconsistent and contradictory since he both upheld the inalienability of human rights and also upheld the priority of the community. As a result, Matolino $(2014,70)$ claims that "[W] hat we know about rights is that they are inviolable and they belong to the individual without any compromise to the reality of the community." On this basis, Matolino (2014, 70) fires at Gyekye that "by reducing rights to a secondary status and promoting the community to an entity that is supposed to benefit from the exercise of these rights," Gyekye subjugates the idea of individual rights which is not different from Menkiti's vision. To remedy this, Matolino proposes his limited communitarianism.

In sum, limited communitarianism states that individual autonomy and rights should be inviolable and inalienable in an Afro-communitarian set-up. Limited communitarianism for him "places strict limitations on the kinds of claims that communitarianism can make in issues of what constitutes personhood" $(2014,160)$. The specific claim that Matolino targeted was making individual autonomy and rights secondary. He suggests that in a world dominated by liberal values, any system of communitarianism we can construct and wish to be viable has to uphold individual autonomy and rights. What is problematic is that Matolino tends to place premium on individual autonomy thus suggesting that limited communitarianism prioritizes the individual over the community, a lopsidedness of a sort. It is hard to see how logic can sustain this lopsidedness that disfavors the community in a supposedly communitarian theory. If this is possible, why then do we call such a system communitarianism rather than outright libertarianism? This line of inquiry has motivated a debate recently between Thaddeus Metz $(2011,2014)$ and Anthony Oyowe $(2013,2014)$. Metz argues that a range of individual endowments are defensible and consistent with the Afro-communitarian tenets, typically, those found in 
the theory of $u b u n t u$. Ubuntu is an Afro-communitarian theory that harps on the values of communion and mutual interdependence as things that are essential to the wellbeing of the individual and the community as an entity. It posits that free willing individuals are better positioned to thrive and succeed in the community if they share and show values of solidarity, care and identity. Metz for example, used the notions of human dignity and capacity for communal relationship which are individual attributes to tease out individual freedom and autonomy in an $u b u n t u$-communitarian set up. However, Oyowe appears to object to this. He raises a counter against the possibility of individual autonomy and rights in a communitarian system like $u$ buntu characterized by the primacy of communal values. Motsamai Molefe (2017a, 2017b) has also recently weighed in on this debate using the frameworks supplied by Menkiti $(1984,2004)$ and Gyekye (1992) which tend to give a false impression that individual endowments and communal values clash. Molefe, unlike Oyowe argues that this clash does not occur and unlike Matolino, endorses Menkiti's position that communal values take precedence over individual endowments. In this work, we object to Oyowe's animadversions and accept Metz's position as tenable insofar as it does not oppose the idea of binary complementarity. We also do not completely accept Matolino's position for reasons already stated above.

It is for the possible weakness which can be drawn as an implication of Matolino's theory that we adopt Eze's realist perspectivism as a realistic model for resolving the individual-community imbroglio. One major difference between Eze's proposal and those of Gyekye and Matolino is that the latter two attempt to pit individual endowments against community values whereas Eze avoided this confrontation and rather opted to think of the individual and the community as complementary and mutually interdependent.

\section{THE EXTENT OF INDIVIDUAL FREEDOM IN AFRO- COMMUNITARIANISM}

We now turn to the main question of this paper as posed earlier; how much space can we allocate to individual freedom without jeopardizing public authority and destroying our civilization; and how much space can we allocate to public authority without endangering humanity and destroying our diversity? In short, what is the extent of freedom that the individual should have in an Afro-communitarian system? Put it in Berlin's $(1967,158)$ own conception, "[W] e must preserve a minimum area of personal freedom if we are not to 'degrade or deny our nature'. We cannot remain absolutely free, and must give up some of our liberty to preserve the rest. But total self-surrender is selfdefeating. What then must the minimum be?"

In both moderate and limited communitarian models of Afro-communitarianism, it would be difficult to determine this minimum because while moderate communitarianism is inconsistent, limited communitarianism is overwhelmingly libertarian as we have argued earlier. This leaves us with the option of realist perspectivism. By Eze's realist perspectivism, we see a framework that is not interested in the competition and power struggle between the individual and the community but rather in establishing binary 
complementarity as the structure of the individual-community relationship. What is important and of central focus is the notion of "nmeko' ${ }^{2}$ otherwise translated as 'relationship.' The relationship between the individual and the community is not about who has the most influence with regards to indices such as power, authority, rights, (in)justice, (in)equality, resources and freedom, etc. No, it is rather about how much each has to contribute to make the state functional and progressive. It is about how each complements the other. It is not about whether personhood is gained at birth or acquired along the line, or biological or bestowed; it is about the quality of personhood one exudes to benefit other persons. It is not about a person being a person through other persons; it is about how much one is able to give of their personhood to better the lot of others. Realist perspectivism could be used and we are using it here to show that what is of utmost importance in the individual-community relationship is not the influence each wields but what each contributes in the relationship of binary complementarity.

When considered from this point of view, one can see that individual freedom is not just possible and necessary but should be construed as a given in Afrocommunitarianism, if without it, we may not be able to conceive of the individualcommunity relationship as contemporaneous and complementary. Just like Berlin conceptualized negative and positive freedoms, we here conceptualize negative and positive relationships. When the individual-community relationship is about who wields more power and influence or who is prior to the other, we may describe it as negative as opposed to when the relationship is about what each could offer which can be described as positive. Our hunch is that realist perspectivism endorses the latter and discounts the former.

Thus, the individual to a very large extent can have ample freedom in the Afrocommunitarian setting insofar as it does not use it to cause any form of harm to others. This makes the three principles of Danny Frederick (1997), namely; harm, cost and pareto important. According to these principles, the individual is to some extent free once he does not harm, inflict cost or decrease another individual's utility in the community. In Afro-communitarianism, positive relationship with others is the mantra. With regards to the individual and their community, this relationship has to be balanced, contemporaneous or should reflect the mode of binary complementarity. This is not quite the same with the vision of some Africanist scholars who have made the notion of relationship a feature in their own discourses. Augustine Shutte (2001, 24 quoted in Molefe 2017a) for example said, "I only become fully human to the extent that I am included in relationship with others." For Bujo (2001, 84 quoted in Molefe 2017a) when one acts in solidarity for the construction of the community, he "allows himself to be brought to completion by this same community so that he can become a person truly." These two visions, though focused on relationship actually fall within the vision of radical communitarians who believe that the community is cardinal to the achievement of personhood. However, personhood, if it must be teased out of realist perspectivism would be a property that is biologically inherent in the individual but which benefit actually depends on what each individual does with his own person (Chimakonam $2019 b)$. In other words, the value of personhood does not lie in the person that carries 
it but in what the individual does with it. It is difficult to determine the worth of an individual's personhood until he commits it to acting, willing and judging. Personhood, though natural is further shaped by nurture and phases of individual life experiences. This is why two individuals like Okonkwo and Ezeudu of Achebe's Things Fall Apart grew in the same community but developed different personalities. Whereas Umuofia, their community exposed the two characters to the same communal values, their life experiences were different and it was the latter that actually shaped their personalities. On this basis, it would be easy to understand the relationship that exists between individuals or between the individual and the community as best when it is complementary.

\section{CONCLUSION}

We have explored the degree or extent of individual freedom in Afrocommunitarianism and tried to show, using Eze's realist perspectivism, how the individual necessarily should enjoy ample freedom in the community. We considered the leading positions in Afro-communitarianism such as Menkiti's radical communitarianism, Gyekye's moderate communitarianism, Matolino's limited communitarianism and Eze's realist perspectivism. Whilst we objected to the vision of the radical communitarians, we found both moderate communitarianism and limited communitarianism slightly inadequate to drive our proposal. Eze's realist perspectivism appears to be an adequate model that can yield our vision of binary complementarity in the relationship between the individual and the community.

In presenting the individual-community relationship as contemporaneous, we were afforded the basis to establish personhood as a property of the individual which is independent of the community and by so doing defend a reasonable level of individual freedom. Our argument was that the individual requires a minimum level of freedom in order to function fully in the community and that his full functioning determines the functioning of the community. The essence of the relationship between the individual and the community is to benefit all but it is also possible for the relationship to be toxic. For example, when one party attempts to lord it over or subsume the other as the vision of the radical communitarians propose, we describe such as a negative relationship. Whereas when the goal of such a relationship is about what each can contribute, we describe it as a positive one. Using realist perspectivism we steered the objective of the individual-community relationship from that of power struggle to mutual progress through complementarity. To defend this type of relationship, it was important to grant the freedom of the individual to function as a self-asserting entity.

However, we can observe certain challenges in the application of realist perspectivism. For example, how would the realist perspective model resolve specific problems in the individual-community relationship like conflict of interests between the community and the individual, or between the distribution of burdens and benefits in the society (which is an obligation on the part of the community or society), and the obligation of individuals to the society? These are not simple issues to be ignored and we are not doing so here. But in the face of no immediate solution, we have decided to 
put these questions down for future research and to inspire discussions among scholars.

\section{NOTES}

1. Jonathan O Chimakonam $(2018,123)$ puts forward two possible versions of communitarianism in extant literature: the version qualified with the predicate 'African,' that is African or Afro-communitarianism and grounded in African logic, and the unqualified version known simply as communitarianism and discussed mostly by Western scholars like Michael Walzer, Michael Sandel, Charles Taylor and Amitai Etzioni, etc., grounded in the Aristotelian logic with its strict bivalence.

2. Jonathan O. Chimakonam (2019a) has provided a detailed definition of this concept.

\section{RE F E R E N C E S}

Berlin, Isaiah. 1967. Two concepts of liberty: four essays on liberty. In Political Philosophy. Edited by A. Quinton. New York: Oxford University Press, pp.141-52.

Bujo, Benezet. 2001. Foundations of an African ethic: beyond the universal claims of Western morality. New York: The Crossroad.

Chimakonam, Jonathan O. 2017. An interrogation of capital punishment in Nigeria's penal system: towards a freedom theory of punishment in African philosophy. In The death penalty from an African perspective: views from Zimbabwean and Nigerian philosophers. Edited by Fainos Mangena and Jonathan. O. Chimakonam. Delaware: Vernon Press, 115-136.

Chimakonam, O. Jonathan. 2018. Can individual autonomy and rights be defended in Afro-communitarianism? Filosofia Theoretica: Journal of African Philosophy, Culture and Religions, 7:2.

Chimakonam, Jonathan O. 2019a. Ezumezu: a system of logic for African philosophy and studies. Cham: Springer.

Chimakonam, Jonathan O, et al. 2019b. A sense-phenomenal look at the problem of personal identity. New conversations on the problems of identity, consciousness and mind. Cham: Springer.

Epistein, Richard.1987. The fundamentals of free speech. Harvard Journal of Law and Public Policy 10 (55).

Eze, Michael O. 2013. What is African communitarianism? Against consensus as a regulative ideal. South African Journal of Philosophy 27(4) 386-399.

Frederick, Danny.1997. The limits of individual freedom: why the principle of right is better than those of harm, cost, pareto or coercion. London: Libertarian Alliance.

Gyekye, Kwame.1992. Person and community in African thought. Person and community: Ghanaian philosophical studies. Edited by Kwasi Wiredu and Kwame Gyekye. Washington DC: Council for Research in Value and Philosophy, 101-120.

Matolino, Bernard. 2009. 'Radicals versus moderates: a critique of Gyekye's moderate communitarianism. South African Journal of Philosophy 28(2), 161-170. 
AFRO-COMMUNITARIANISM AND THE QUESTION OF INDIVIDUAL FREEDOM 49

Matolino, Bernard. 2014. Personhood in African philosophy. Pietermaritzburg: Cluster Publications.

Mbiti, John. 1970. African religions and philosophies. New York: Doubleday and Company.

Menkiti, Ifeanyi. 1984. Person and community in African traditional thought. In African philosophy: An introduction. Edited by Richard A, Wright. Lanham: University Press ofAmerica,171-181.

Menkiti, Ifeanyi. 2004. On the normative conception of a person. In Companion to African philosophy. Edited by Kwasi Wiredu. Oxford: Blackwell Publishing, 324-331.

Molefe, Motsamai. 2017a. Critical comments on afro-communitarianism: The community versus individual. Filosofia Theoretica: Journal of African Philosophy, Culture and Religions 6(1)1-22.

Molefe, Motsamai. 2017b. Personhood and rights in an African tradition. Politikon: South African Journal of Political Studies 45(2) 217-231.

Metz, Thaddeus. 2011. Ubuntu as a moral theory and human rights in South Africa. African Human Rights Law Journal 11.532-559.

Metz, Thaddeus. 2014. African values and human rights as two sides of the same coin: A reply to Oyowe. African Human Rights Law Journal 14(2). 306-321.

Nozick, Robert. 1974. Anarchy, state and utopia. Oxford: Blackwell Publishers.

Nussbaum, Martha C. 2003. Political liberalism and respect: a response to Linda Barclay. Nordic Journal of Philosophy 4. 25-44.

Nussbaum, Martha C. 2015. Political liberalism and global justice. Journal of

Global Ethics, 11 (1). 68-79.

Oyowe, O. Anthony. 2013. Strange bedfellows: Rethinking Ubuntu and human rights in South Africa. African Human Rights Law Journal 13. 103-124.

Oyowe, O. Anthony. 2014. An African conception of human rights? comments on the challenges of relativism. Human Rights Review 15(3). 329-347.

Rawls, John. 1993. Political liberalism: Expanded edition. New York: Columbia University Press.

Rawls, John. 1971. Revised edition 1999. A theory of justice. Cambridge Mass.: Harvard University Press.

Sen, Amartya. 1999. Development as freedom. New York: Alfred A. Knopf.

Sen, Amartya. 2009. The idea of justice. Cambridge, Massachusetts: The Belknap Press of Harvard University Press.

Shutte, Augustine. 2001. Ubuntu: an ethic for a new South Africa. Pietermaritzburg: Cluster Publications.

Wiredu, Kwasi.1992. Moral foundations of an African culture. In Person and community: Ghanaian philosophical studies. Edited by Kwasi Wiredu and Kwame Gyekye Washington DC: Council for Research in Values and Philosophy. 192-206.

Submitted: 5 January 2019; revised: 22 October 2019

Philosophia: International Journal of Philosophy

Vol. 21, No. 1, January 2020

ISSN 2244-1875 